\title{
Review
}

\section{Present State of High Purity Metal Industry in Japan}

\author{
Koemon FUNAKI \\ Research Laboratory of Resources Utilization, \\ Tokyo Institute of Technology, Tokyo
}

Received May 30, 1966

"High purity metal" is a word widely used, today. As to what is meant by this word, the author entertains an opinion that a metal may be defined as a "high purity metal" when it is refined so intensively as to be substantially changed in properties, or acquire quite new properties, thus being given new industrial uses on account of these new properties. It is quite natural, therefore, that the purity of a high purity metal varies according to the state of progress of the industries involved, and the kind of metal.

The refining of copper about 1927 may be referred to as to the first production of a high purity metal in Japan. At that time, the domestic copper had a low electrical conductivity, and thus could not be used in the production of conductors. However, upon discovering that this low conductivity was due to the presence of gold, silver and etc. in the copper, removal of these metals from the copper enabled its use as a conducting material. At present, there is no need to dwell upon the fact that high purity metals are playing important roles in the development of industries concerned with electronics, atomic power, high velocity flying objects and etc.
As mentioned above, many kinds of high purity metals are now being produced in Japan to fulfill the demands from various fields. At the same time, active sturies are being made on the production, properties and utilization of more high purity metals.

In this paper, the present state of the production of several high purity metals in Japan is reviewed.

\section{Production}

\section{Germanium}

Being restricted by the available resources, high purity germanium is not being produced from its ores, but by reduction of germanium oxide either imported or recovered from germanium scrap, the production being quite peculiar as compared with the production of their metals.

The production of germanium and its oxide in the last several years ${ }^{1 / 2)}$, and the productive capacity of other producers 3 ) are shown in Tables 1 and 2, respectively.

Although the production decreased sharply in 1963 because of the increasing stock of product, the producers have worked at their full capacity since the 
Table 1 Annual Production of Germanium and its Oxide (kg)

\begin{tabular}{c|c|c}
\hline \hline Year & Germanium oxide & Germanium \\
\hline 1960 & 11,388 & 21,362 \\
1961 & 14,724 & 24,373 \\
1962 & 18,619 & 22,368 \\
1963 & 14,385 & 14,593 \\
1964 & 20,912 & 23,859 \\
\hline
\end{tabular}

Table 2 Monthly Productive Capacity of Producers of Germanium and its Oxide $(\mathrm{kg})$

\begin{tabular}{c|c|c}
\hline \hline Company & $\begin{array}{c}\text { Germanium } \\
\text { oxide }\end{array}$ & Germanium \\
\hline $\begin{array}{c}\text { Tokyo Denshi Yakin } \\
\text { Laboratory }\end{array}$ & 300 & 250 \\
$\begin{array}{c}\text { Tokyo Electronic } \\
\text { Metals Co., Ltd. }\end{array}$ & 500 & 1,020 \\
$\begin{array}{c}\text { Mitsui Mining \& } \\
\text { Smelting Co., Ltd. }\end{array}$ & 300 & 20 \\
Japan Electric \\
Metal Co., Ltd.
\end{tabular}

latter half of 1963 because of the brisk demand for germanium transistors. However, it being considered that silicon may gradually replace germanium in the near future, the merits of germanium and silicon are now under comparative examination from the industrial point of view.

\section{Silicon}

In contrast with germanium, the production of silicon is not restricted by the problem of resources.

Hydrogen reduction and thermal decomposition of trichlorosilane, thermal decomposition of silane, hydrogen reduction of silicon tetrachloride and etc. have been adopted for the production of silicon.

The production of silicon (polycrystalline $)^{1)}, 2$, and the productive capacities of its producers ${ }^{4)}$ are shown in Tables 3 and 4 , respectively.
Table 3 Annual Production of Silicon (polycrystalline)

\begin{tabular}{l|c}
\hline \hline Year & Production $(\mathrm{kg})$ \\
\hline 1959 & 24 \\
1960 & 2,310 \\
1961 & 3,921 \\
1962 & 6,316 \\
1963 & 10,743 \\
1964 & 13,629 \\
\hline
\end{tabular}

Table 4 Monthly Productive Capacity of Producers of Silicon (polycrystalline)

\begin{tabular}{l|c}
\hline \hline \multicolumn{1}{c|}{ Company } & Capacity (kg) \\
\hline $\begin{array}{l}\text { Shin-Etsu Chemical Industry } \\
\text { Co., Ltd. }\end{array}$ & 250 \\
Komatsu Electronic Metals & 300 \\
Co., Ltd. & 150 \\
Japan Electric Metal Co., Ltd. & 420 \\
Chisso Co., Ltd. & 250 \\
Osaka Titanium Co., Ltd. & 100 (Stopped \\
Tokai Electrode Mfg. Co., \\
Ltd.
\end{tabular}

Notwithstanding the increase in production of silicon, most of the producers did not obtain a reasonable profit from this product. It is considered that this problem is mainly due to the small production units of the producers and the low market price of silicon, and that this is to be dissolved in the near future.

\section{Uranium}

Tokai Refinery of Atomic Fuel Corp. has put a test plant in operation to produce uranium from imported uranium concentrate (yellow cake), the product being not only offered to Japan Atomic Energy Research Institute but also to others for various experiments and studies. Mitsubishi Metal Mining Co., Ltd., Furukawa Electric Co., Ltd. and Sumitomo Metal Mining Co., Ltd., investigated the produc- 
tion of uranium in their own test plants, and the attempts of most of these companies were successful.

The production of producers of uranium is shown in Table 5. ${ }^{5), 6)}$

Table 5 Annual Production of Producers of Uranium $(\mathrm{kg})$

\begin{tabular}{l|r|r|r|r}
\hline Company & 1961 & 1962 & 1963 & 1964 \\
\hline $\begin{array}{l}\text { Atomic Fuel } \\
\text { Corp. }\end{array}$ & 14,789 & 17,435 & 17,836 & 2,683 \\
$\begin{array}{c}\text { Mitsubishi Metal } \\
\text { Mining Co., Ltd. }\end{array}$ & 10 & 30 & 6 & 4 \\
\hline \begin{tabular}{c} 
Total \\
\hline
\end{tabular} & 14,799 & 17,465 & 17,842 & 2,687 \\
\hline
\end{tabular}

On the other hand, Atomic Fuel Corp. which has tested a pilot plant for the production of yellow cake from the domestic ore has recently developed a process in which the production of yellow cake is directly connected with the production of uranium. This process comprises the preparation of yellow cake by a sulfuric acid leaching of the domestic ore, the preparation of uranium tetrafluoride from the cake by a wet method called "Excer Process" and the preparation of uranium by magnesium reduction of the tetrafluoride.

\section{Tantalum}

Tantalite containing more than 60 per cent tantalum pentoxide is being used as a raw material, for the demand of niobium which is contained in tantalite is very small in Japan at present. At the present time, potassium fluotantalite imported is being used with tantalite by some producers, for the production of tantalum may thus be increased without the increase of the facilities necessary for the processing of ore. Tantalum scrap offered by manu- factures of electronic instruments is aisu being re-used as a raw material.

The production of producers of capac$i$ tor grade and metallurgical grade tantalum ${ }^{5), 7)}$ is shown in Table 6.

Table 6 Annual Production of Producers of Tantalum $(\mathrm{kg})$

\begin{tabular}{l|r|r|r}
\hline \hline Year & 1961 & 1962 & 1963 \\
Company & 542 & 630 & 540 \\
\hline $\begin{array}{l}\text { Komatsu Manufacturing } \\
\text { Co., Ltd. }\end{array}$ & 379 & 816 & 876 \\
$\begin{array}{l}\text { Shin-Etsu Chemical } \\
\text { Industry Co., Ltd. }\end{array}$ & 304 & 545 & 1,644 \\
Nippon Soda Co., Ltd. & - & 325 & 1,052 \\
Tokyo Denkai Co., Ltd. & 1,225 & 2,316 & 4,112 \\
\hline
\end{tabular}

For the production of tantalum, sodium reduction of potassium fluotantalite has been adopted by Nippon Soda Co., Ltd., while the electrolytic method had been adopted by the other producers. However, the sodium reduction method has recently been adopted by producers other than Nippon Soda Co., Ltd. too, because of reasons such as that this method is rather preferable for obtaining capacitor grade tantalum powder.

As shown in Table 6, the production in 1963 was larger than that in 1962, for the increase in the consumption of the domestic product in place of imported tantalum.

At present, the productive capacity of each producer is about $200 \sim 300$ kilograms per month and remains as yet far from the scale of a commercial production.

To assure the steady development of the production of tantalum, it is necessary to facilitate the obtaining of the raw material, to improve the ties between the producers and the electronic industry, which is a large consumer, and to exploit new potential uses of tantalum. Further, 
Table 9 Annual Production of Producers of $\mathrm{M}_{\text {agnesium from Anhydrous }}$ Magnesium Chloride (metric tons)

\begin{tabular}{l|r|r|r|r|r|r}
\hline \multicolumn{1}{c|}{ Year } & 1959 & 1960 & 1961 & 1962 & 1963 & 1964 \\
Company & & & & & & \\
\hline Osaka Titanium Co., Ltd. & - & - & 15 & 355 & 713 & 1,003 \\
Toho Titanium Co., Ltd. & 1,634 & 1,444 & 1,485 & 909 & 699 & 1,244 \\
Asahi Chemical Industry Co., Ltd. & 678 & 719 & 645 & 395 & - & - \\
Sumitomo Chemical Co., Ltd. & 604 & 741 & 631 & 274 & - & - \\
Nippon Soda Co., Ltd. & 14 & 112 & - & - & - & - \\
\hline \multicolumn{1}{c}{ Total } & 2,930 & 3,016 & 2,776 & 1,933 & 1,412 & 2,247 \\
\hline
\end{tabular}

tons in 1964.

The production of magnesium in the last several years 1),11) is shown in Table 8.

On the other hand, the production of magnesium by the method of electrolysis of anhydrous magnesium chloride recovered from magnesium reduction of titanium tetrachloride is shown in Table 9.

\section{Aluminum}

In Japan, aluminum of a purity higher than 99.2 per cent is called high purity

Table 10 Annual Production of High Purity Aluminum (metric tons)

\begin{tabular}{c|c}
\hline \hline Year & Production \\
\hline 1961 & 1,177 \\
1962 & 1,929 \\
1963 & 1,869 \\
1964 & 1,938 \\
\hline
\end{tabular}

Table 11 Annual Production of High Purity Aluminum of Various Purity-grades (metric tons)

\begin{tabular}{c|r|r}
\hline \multicolumn{1}{l|}{ Year } & 1961 & 1962 \\
\hline$>99.99$ per cent & 1,056 & 1,861 \\
$>99.95$ per cent & 106 & 58 \\
$>99.92$ per cent & 15 & 10 \\
\hline Total & 1,177 & 1,929 \\
\hline
\end{tabular}

aluminum, because this is superior in electrical conductivity, light reflection, corrosion resistivity and etc. to the regular grade aluminum.

High purity aluminum is mainly used for making the electrolytic condensers for television and radio sets, and reflecting mirror.

At present, high purity aluminum is being produced by Nippon Light Metal Co., Ltd. and Sumitomo Chemical Co., Ltd. using the triple layer electrolytic refining method.

The production of high purity aluminum $^{1), 12)}$ and that of various purity-grades ${ }^{1)}$ are shown in Tables 10 and 11, respectively.

Altogether, 6 electrolytic cells of 45,000 amperes and 18 electrolytic cells of 32,500 amperes are installed in Japan. It was reported that these cells were operated at 82.5 per cent of capacity in 1962.

\section{Other high purity metals}

Besides the high purity metals mentioned above, high purity tellurium, indium, gallium, bismuth, cadmium, selenium, antimony, arsenic, zinc, lead, copper, tin, gold, silver and etc. are now being produced. Their grades and productive capacities ${ }^{13)}$ are summarized in Table 12.

The production of reactor grade and 
it is important to encourage the demand for the niobium coexisting in the ore.

\section{Titanium}

The production of titanium was begun in 1953, the product being exported to U.S.A., and has rapidly grown up. However, being affected by the decrease in the manufacturing of military jet planes in U.S.A. after 1957, the export to U.S.A. had remarkably decreased, and the production of titanium in Japan had to be curtailed. On account of this change in the situation, efforts were steadily made to exploit the domestic demand for titanium as a corrosion resisting material for chemical industry, as well as to rationalize the process of production.

As the export to U.S.A. for military uses, the reference from U.S.A. for civilian demand and the distribution for civilian demand in Japan have increased since 1964 , the producers are now operating at their full capacity

The production and the distribution of titanium sponge ${ }^{8), 9)}$ are shown in Table 7.

Table 7 Annual Production and Distribution of Titanium Sponge (metric tons)

\begin{tabular}{c|c|c|c|c}
\hline \hline & & \multicolumn{3}{|c}{ Distribution } \\
\cline { 3 - 5 } Year & Production & Export & $\begin{array}{c}\text { Domestic } \\
\text { consumption }\end{array}$ & Total \\
\hline 1959 & 2,477 & 1,798 & 259 & 2,057 \\
1960 & 2,307 & 1,933 & 394 & 2,327 \\
1961 & 2,283 & 1,567 & 545 & 2,112 \\
1962 & 1,543 & 1,239 & 585 & 1,824 \\
1963 & 1,759 & 1,282 & 863 & 2,145 \\
1964 & 2,993 & 1,606 & 1,500 & 3,106 \\
\hline
\end{tabular}

At present, titanium sponge is being produced by Osaka Titanium Co., Ltd. and Toho Titanium Co., Ltd.

A mixture of domestic titanium slag and imported rutile (or ilmenite) is used as the raw material, and the Kroll process was adopted.
In order to fulfill the recent vigorous demand, the productive capacities per month of Osaka Titanium Co., Ltd. and Toho Titanium Co., Ltd. were increased in November, 1964, up to 200 metric tons with an addition of 50 metric tons and up to 170 metric tons with an addition of 30 metric tons, respectively. Both companies are planning to increase the productive capacity ${ }^{10)}$

\section{Magnesium}

The production of magnesium was begun as early as 1929 and had steadily expanded with the development of the aircraft industry. However, since aircraft production stopped at the end of World War II, the production of magnesium was also halted. When the production of titanium, which requires high purity magnesium as a reducing agent, was born, the production of magnesium again started in 1954 .

At present, the production of magnesium is being carried out by Furukawa Magnesium Co., Ltd. who uses the domestic dolomite ore as the raw material, and utilizes the ferrosilicon reduction process. This company has remarkably increased her productivity by improving the technique of production. Thus, the monthly productive capacity per one reduction furnace was only 13 metric tons in 1960 , but increased to 17 metric tons in 1961 and to 25 metric tons in 1964, the productivity in 1964 being, about twice that in 1960. The company's annual productive capacity amounted to 5,700 metric

Table 8 Annual Production of Magnesium

\begin{tabular}{c|c}
\hline \hline Year & Production (metric tons) \\
\hline 1959 & 1,563 \\
1960 & 2,144 \\
1961 & 2,247 \\
1962 & 2,087 \\
1963 & 2,434 \\
1964 & 2,736 \\
\hline
\end{tabular}


Table 12 Monthly Productive Capacity of Producers of Various High Purity Metals (kg)

\begin{tabular}{|c|c|c|c|}
\hline Metal & Purity (per cent) & Company & Capacity \\
\hline Tellurium & $\begin{array}{l}>99.999,>99.9999 \\
\quad>99.999 \\
>99.999\end{array}$ & $\begin{array}{l}\text { Mitsubishi Metal Mining Co., Ltd. } \\
\text { Mitsui Mining \& Smelting Co., Ltd. } \\
\text { Nippon Mining Co., Ltd. }\end{array}$ & $\begin{array}{l}500 \\
100 \\
100 \\
\end{array}$ \\
\hline Indium & $\begin{array}{l}>99.999,>99.9999 \\
>99.999 \\
>99.999\end{array}$ & $\begin{array}{l}\text { Mitsubishi Metal Mining Co., Ltd. } \\
\text { Mitsui Mining \& Smelting Co., Ltd. } \\
\text { Tokyo Electronic Metals Co., Ltd. }\end{array}$ & $\begin{array}{r}10 \\
100 \\
200 \\
\end{array}$ \\
\hline Gallium & $>99.999,>99.9999$ & Mitsubishi Metal Mining Co., Ltd. & 5 \\
\hline Bismuth & $\begin{array}{l}>99.999,>99.0000 \\
>99.999 \\
>99.9999 \\
<99.999\end{array}$ & $\begin{array}{l}\text { Mitsubishi Metal Mining Co., Ltd. } \\
\text { Nippon Mining Co., Ltd. } \\
\text { Nippon Soda Co., Ltd. } \\
\text { Mitsui Mining \& Smelting Co., Ltd. }\end{array}$ & $\begin{array}{l}500 \\
100 \\
100 \\
200\end{array}$ \\
\hline Cadmium & $\begin{array}{l}<99.9999 \\
>99.999 \\
>99.998 \\
>99.999\end{array}$ & $\begin{array}{l}\text { Nippon Soda Co., Ltd. } \\
\text { Mitsui Mining \& Smelting Co., Ltd. } \\
\text { Nippon Mining Co., Ltd. } \\
\text { Furukawa Electric Co., Ltd. }\end{array}$ & $\begin{array}{r}50 \\
18,000\end{array}$ \\
\hline Selenium & $\begin{array}{c}>99.995 \\
>99.999,>99.9999 \\
>99.999 \\
>99.99 \\
\end{array}$ & $\begin{array}{l}\text { Nippon Mining Co., Ltd. } \\
\text { Mitsubishi Metal Mining Co., Ltd. } \\
\text { Mitsui Mining \& Smelting Co., Ltd. } \\
\text { Sumitomo Metal Mining Co., Ltd. }\end{array}$ & $\begin{array}{r}1,900 \\
1,000 \\
100 \\
- \\
\end{array}$ \\
\hline Antimony & $\begin{array}{l}>99.999,>99.9999 \\
>99.999\end{array}$ & $\begin{array}{l}\text { Mitsubishi Metal Mining Co., Ltd. } \\
\text { Mitsui Mining \& Smelting Co., Ltd. }\end{array}$ & $\begin{array}{l}50 \\
50\end{array}$ \\
\hline Arsenic & $>99.999,>99.9999$ & Mitsubishi Metal Mining Co., Ltd. & 5 \\
\hline Zinc & $\begin{array}{l}>99.999,>99.9999 \\
>99.9999\end{array}$ & $\begin{array}{l}\text { Mitsui Mining \& Smelting Co., Ltd. } \\
\text { Nippon Soda Co., Ltd. }\end{array}$ & $\begin{array}{r}1,000 \\
50 \\
\end{array}$ \\
\hline Lead & $\begin{array}{l}>99.999 \\
>99.999\end{array}$ & $\begin{array}{l}\text { Mitsui Mining \& Smelting Co., Ltd. } \\
\text { Mitsubishi Metal Mining Co., Ltd. }\end{array}$ & $\begin{array}{r}100 \\
50\end{array}$ \\
\hline Copper & $>99.999$ & Mitsubishi Metal Mining Co., Ltd. & 2,000 \\
\hline Tin & $>99.999$ & Mitsubishi Metal Mining Co., Ltd. & 70 \\
\hline Gold & $>99.999$ & Nippon Mining Co, , Ltd. & 1.5 \\
\hline Silver & $>99.999$ & Mitsubishi Metal Mining Co., Ltd. & 10 \\
\hline
\end{tabular}

commercial grade zirconium had been attempted by Toyo Zirconium Co., Ltd., but was stopped in 1962 because of the stagnation of export and so on. The facilities and technique for the production have been supervised by Central Research Laboratory of Nippon Mining Co., Ltd. who is maintaining the facilities and technique for possible future developments.

\section{Conclusion}

During World War II, many high purity metals which had previously never been beyond the object of basic scientific research were taken up as industrial materials and their excellent properties have contributed to a remarkable progress in the fields of science and engineering. Since then their production made a rapid development till it secured the present unique position in the metal industry in Japan. 
As to the present position occupied by the high purity metals as industrial materials, it is possible to say that besides the discovery of their excellent properties the newly exploited techniques of refining and working which enabled the high purity metals to be prepared on the industrial scales, such as those used in obtaining germanium for transistors, which vigorously calls for a purity as high as 99.9999999 per cent, or zirconium for atomic reactors, the allowable content of hafnium of which is of the order of one millionth, contribute to the developments of the science and engineering.

Various kinds of high purity metals prepared by highly advanced techniques will make important materials that play an active part in the industry of the socalled Space Age.

In this paper, beginning with proposing an industrial definition of high purity metals, the present state of the production and consumption of the high purity metals in this country are described.

\section{Literature:}

1) Ministry .of International Trade and In-
Justry, "A General Survey of the NonFerrous Metal Industry" (1963).

2) Japan Society of Newer Metals, Newer Metal Industry No. 98, 28 (1964); No. 110, 32 (1965).

3) Japan Society of Newer Metals, Newer Metal Industry No. 100, 24 (1964).

4) Japan Society of Newer Metals, Newer Metal Industry No. 100, 26 (1964).

5) Japan Association of Metals for Atomic Energy, J. Newer Metals №. 62 (1961)No. 79 (1962).

6) Japan Society of Newer Metals, Newer Metal Industry $\mathrm{N}_{0} .80$ (1962) - No. 109 (1965).

7) Japan Society of Newer Metals, Newer Metal Industry No. 80 (1962) - No. 97 (1964).

8) Japan Titanium Socicty, Titanium 12, 168 (1964).

9) Private communication from Japan Titanium Society.

10) Japan Titanium Society, Titanium Data No. 2, 3 (1965).

11) Japan Society of Newer Metals, Newer Metal Industry No. 98 (1964) - No. 109 (1965).

12) Light Metals Society, Keikinzoku-Joho No. 411, 4(1964), No. 422, 6(1965).

13) Japan Society of Newer Metals, Newer Metal Industry No. 100, 20 (1964). 